\title{
MENELUSURI SUFI DIGITAL
}

\author{
Ismail Suardi Wekke \\ Sekolah Tinggi Agama Islam Negeri (STAIN) Sorong \\ Email: iswekke@gmail.com
}

\begin{abstract}
ABSTRAK
Perangkat digital menyentuh semua aspek kehidupan. Terdapat peluang untuk melakukan konvergensi aktifitas kehidupan dengan gawai yang tersedia sebagai sebuah bagian utama kehidupan. Termasuk dalam kehidupan keberagamaan. Terjadi dinamisasi kehidupan yang berubah akibat pola penggunaan gawai. Salah satu aspeknya adalah sufisme yang menjadi aktifitas beragama. Hanya saja, untuk menghindari kerancuan dalam memberi istilah maka perlu penelaahan dan pengayaan data untuk kemudian menamankan aktifitas tersebut sebagai sufi digital. Sebagaimana istilah yang sudah berterima seperti perpustakaan digital, pembelajaran digital, ekonomi digital, dll.
\end{abstract}

Kata kunci: sufi digital, keberagamaan, perangkat teknologi

\section{Pendahuluan}

Corbin (2012) menjelaskan bahwa Ibnu Arabi sebagai salah satu penggagas sufisme. Kemudian Ernst (2017) menambahkan bahwa sufisme sesungguhnya walau belum disebut di zaman Rosulullah Muhammad SAW, sudah ada sejak itu. Sufisme dalam perkembangannya melalui perjumpaan dengan budaya popular (Van Bruinessen, 2009). Buya Hamka menyebut adanya sufisme modern (Sutoyo, 2015) terkait dengan manusia modern. Itu bisa terlihat dalam Tafsir Al-Azhar yang berkait dengan pandangan-pandangan sufi dan juga tasawuf (Hidayat, 2015).

Dengan tidak adanya batas-batas teritorial kemudian memungkinkan penyebaran informasi tanpa sekat sama sekali. Termasuk wujudnya sufi melintasi antarbangsa (Qureshi, 2003). Walaupun di dunia modern, terdapat penolakan namun tidak dianggap sebagai perilaku tradisional (Sirriyeh, 2014). Justru di Indonesia, sufisme dianggap sebagai bagian dari perilaku manusia moderen (Howell, 2007). Artikel ini berupaya untuk mengidentifikasi kaitan antara sufisme dengan keberadaan perangkat teknologi informasi.

\section{Ilmu Sosial, Digital, dan Keberagamaan}

Ruppert dan Savage (2013) sudah memberikan peringatan perlunya rekonstruksi dalam ilmu sosial terkait dengan hadirnya teknologi digital. Namun perlu sejak awal dibedakan antara digital dengan teknologi informasi. Penerapan teknologi informasi tidak serta merta bisa dinamai sebuah proses digital. Azman, Salman, Razak, Hussin, Hasim, \& Hassan (2014) sejak awal melihat bahwa teknologi komunikasi dan informasi merupakan bagian dari konsep digital. 
Hanya saja, penggunaan teknologi informasi akan membentuk lingkungan digital (Shah, Cappella, \& Neuman, 2015). Sebagaimana kebiasaan membaca buku berbentuk digital, dinamakan dengan buku eletronik. Tetapi tidak disebut dengan buku digital.

Berry (2012) menginisiasi istilah digital untuk digunakan dalam ilmu sosial. Sebagai sebuah pemahaman awal, narasi Berry sejauh ini hanya mengemukakan peluang-peluang pemanfaatan sarana digital dalam pengembangan ilmu sosial.

Sebuah perpustakaan digital (Februariyanti \& Zuliarso, 2012) merupakan bagian-bagian dari buku eletronik dan sistem otomasi. Dengan demikian, konsepsi sebuah digital tetap perlu diuji (Levy \& Marshall, 1995). Penggunaan teknologi, tidak serta merta kemudian disebut dengan digital. Bahkan kemudahan-kemudahan untuk perangkat perpustakaan memungkinkan masih sebatas praktik sosial dan bukan ekpansi digital. Melainkan fasilitas untuk memudahkan pengelolaan. Sementara praktik yang ada tetap saja seperti praktik yang ada selama ini.

Sebagaimana pembelajaran digital ditopang oleh perangkat pembelajaran daring (dalam jaringan) yang menjadi bagian proses transfer pengetahuan (Rosenberg \& Foshay, 2002). Digital menjadi penanda secara makro, tetapi tidak digunakan secara mikro. Walaupun selalu saja perlu diperhatikan kembali bahwa apapun perangkat yang ada, selalu saja memiliki keterbatasan berbanding dengan interaksi manusia (Winner, 2010). Sehingga pesantren hanya menggunakan teknologi dalam batas-batas tertentu (Wekke \& Lubis, 2008)

Adapun potret sufi digital, memungkinkan untuk dieksplorasi. Namun diingatkan oleh James (2008) jangan sampai terjadian kekacauan makna antara instrument dan bentuk. Jikalau ada konsepsi untuk menamakan sufi digital, maka perlu identifikasi instrumen atau pilar yang menopang konsepsi secara makro. Tahap awal dalan pengajaran dan pembelajaran, keberadaan teknologi hanya semata-mata menjadi media saja (Wekke \& Lubis, 2011). Begitu pula di pesantren, teknologi dimanfaatkan untuk membantu proses belajar mengajar (Wekke \& Hamid, 2013). Dalam konteks pendidikan, maka lingkungan pembelajaran akan menjadi sebuah konsepsi digital (Wekke \& Sahlan, 2014). Tetapi tidak disebut dengan pendidikan digital (Bakti \& Meidasari, 2014).

Terkait dengan sufi pada penggunaan instrumen teknologi informasi dinamakan sebagai komunitas virtual (Piraino, 2016). Adapun ajaran Gulen masih tetap menggunakan pola yang sama sekali tidak dikaitkan dengan digitalisasi (Kim, 2008). Sementara Haramain (2011) secara khusus membahas era digital yang dikaitkan dengan tasawuf, tetapi sebatas memberikan analisis tentang perubahan pandangan tentang tasawuf dalam kondisi kontemporer. Beberapa sarjana menggunakan istilah sufism dikaitkan dengan cyber sufism (Milani \& Possamai, 2013), online sufism (Cheruvallil-Contractor, 2013), sufism on the web (Rausch, 2008), on-line ritual (Larsson, 
2003). Tidak saja itu, keberagamaan dalam penggunaan teknologi informasi bahkan terkait dengan separatisme (Gladney, 2017). Juga terdapat akitivis di dunia cyber (Iqbal, 2017). Tetapi ini bukan gejala abad 21 saja. Sejak 1765 teknologi sudah digunakan dalam aktifitas sufisme (Eaton, 2012).

\section{Penutup}

Terdapat peluang untuk mengekplorasi sufi digital menjadi sebuah konsepsi dalam memotret sebuah keberagamaan. Sehingga perilaku moderen dalam beragama untuk dijadikan sebagai sebuah istilah dalam memperkenalkan fenomena. Penggunaan sarana eletronik tidak lagi sebatas pada keperluan administratif. Tetapi sudah menjangkau komunikasi keagamaan. Sehingga ini akan menjadi sebuah peluang untuk menemukenali aktifitas beragama secara luas.

\section{Daftar Pustaka}

Al-Haramain, E. (2011). Shifting orientation in Sufism: its development and doctrine adjustment in history. IJIMS, I(2).

Azman, H., Salman, A., Razak, N. A., Hussin, S., Hasim, M. S., \& Hassan, M. A. (2014). Determining digital maturity among ICT users in Malaysia. Jurnal Komunikasi: Malaysian Journal of Communication, 30(1).

Bakti, A. F., \& Meidasari, V. E. (2014). Trendsetter Komunikasi di Era Digital: Tantangan dan Peluang Pendidikan Komunikasi dan Penyiaran Islam. Jurnal Komunikasi Islam, 4(1).

Berry, D. M. (2012). Introduction: Understanding the digital humanities. In Understanding digital humanities (pp. 1-20). Palgrave Macmillan, London.

Cheruvallil-Contractor, S. (2013). Online Sufism-Young British Muslims, Their Internet "Selves" and Virtual Reality. Sufism in Britain, London: Continuum, 161-76.

Corbin, H. (2013). Creative imagination in the Sufism of Ibn'Arabi. Routledge.

Eaton, N. (2012). Nomadism of colour: Painting, technology and waste in the chromo-zones of colonial India c. 1765-c. 1860. Journal of Material Culture, 17(1), 61-81.

Ernst, C. W. (2017). Sufism: An introduction to the mystical tradition of Islam. Shambhala Publications.

Februariyanti, H., \& Zuliarso, E. (2012). Rancang bangun sistem perpustakaan untuk jurnal elektronik. Dinamik, 17(2).

Gladney, D. C. (2017). Cyber-Separatism, Islam, and the State in China. In Identity Conflicts (pp. 113-132). Routledge.

Hidayat, U. T. (2015). Tafsir Al-azhar: Menyelami Kedalaman Tasawuf Hamka. Buletin AlTuras, 21(1), 49-76.

Howell, J. D. (2007). Modernity and Islamic spirituality in Indonesia's new Sufi networks. Sufism and the'Modern'in Islam, 217-240.

Iqbal, A. M. (2017). Cyber-activism and the Islamic Salafi movement in Indonesia (Doctoral dissertation, Murdoch University).

James, J. (2008). Digital preparedness versus the digital divide: A confusion of means and ends. Journal of the American Society for Information Science and Technology, 59(5), 785-791.

Kim, H. C. (2008). The nature and role of Sufism in contemporary Islam: A case study of the life, thought and teachings of Fethullah Gülen. Temple University.

Larsson, G. (2003). On-line rituals: a new field of research: neo-pagan and Muslim cyber rituals. Scripta Instituti Donneriani Aboensis, 18, 118-130. 
Levy, D. M., \& Marshall, C. C. (1995). Going digital: a look at assumptions underlying digital libraries. Communications of the ACM, 38(4), 77-84.

Liu, Z. (2005). Reading behavior in the digital environment: Changes in reading behavior over the past ten years. Journal of documentation, 61(6), 700-712.

Milani, M., \& Possamai, A. (2013). The Nimatullahiya and Naqshbandiya Sufi orders on the internet: the cyber-construction of tradition and the McDonaldisation of spirituality. Journal for the Academic Study of Religion, 26(1), 51-75.

Piraino, F. (2016). Between real and virtual communities: Sufism in Western societies and the Naqshbandi Haqqani case. Social Compass, 63(1), 93-108.

Qureshi, R. (2003). Lineage, shrine, qawwali, and study circle: Spiritual kinship in transnational Sufism. Religious Studies and Theology, 22(1), 63.

Rausch, M. (2008). Encountering Sufism on the web. Sufism Today: Heritage and Tradition in the Global Community, 159.

Rosenberg, M. J., \& Foshay, R. (2002). E-learning: Strategies for delivering knowledge in the digital age. Performance Improvement, 41(5), 50-51.

Ruppert, E., Law, J., \& Savage, M. (2013). Reassembling social science methods: The challenge of digital devices. Theory, culture \& society, 30(4), 22-46.

Shah, D. V., Cappella, J. N., \& Neuman, W. R. (2015). Big data, digital media, and computational social science: Possibilities and perils. The ANNALS of the American Academy of Political and Social Science, 659(1), 6-13.

Sirriyeh, E. (2014). Sufis and anti-Sufis: The defence, rethinking and rejection of Sufism in the modern world. Routledge.

Sutoyo, S. (2015). Tasawuf Hamka dan Rekonstruksi Spiritualitas Manusia Modern. ISLAMICA: Jurnal Studi Keislaman, 10(1), 108-136.

Van Bruinessen, M. (2009). Sufism, 'Popular'Islam and the Encounter with Modernity. Islam and modernity: key issues and debates, 125-157.

Wekke, I. S., \& Hamid, S. (2013). Technology on language teaching and learning: a research on Indonesian pesantren. Procedia-Social and Behavioral Sciences, 83, 585-589.

Wekke, I. S., \& Lubis, M. A. (2008). A Multicultural approach in Arabic language teaching: creating equality at Indonesian pesantren classroom life. Sosiohumanika, 1(2).

Wekke, I. S., \& Lubis, M. A. (2011). Educational Technology on Teaching and Learning of Integrated Islamic Education in Brunei Darussalam. Ulumuna, 15(1), 185-204.

Wekke, I. S., \& Sahlan, A. (2014). Strategy in creating school environment: lessons from high schools in indonesia. Procedia-Social and Behavioral Sciences, 143, 112-116.

Winner, L. (2010). The whale and the reactor: A search for limits in an age of high technology. University of Chicago Press. 